\title{
Budget of daily activity in wood lemming Myopus schisticolor (Lilljeborg, 1884) (Rodentia: Cricetidae)
}

\author{
Alexander D. Mironov, Ol'ga M. Golubeva, Tat'yana Yu. Chistova \\ \& Lyudmila L. Danilkina
}

\begin{abstract}
Daily activity of wood lemming was studied in a manege of $10 \mathrm{~m}^{2}$. Seven series of multidaily studies during various natural photoperiods have been conducted. The budget of daily activity of wood lemming in experiments consists mainly of feeding behavior and moving activity. Feeding activity occupies about $10 \%$ of the daily budget, and fluctuates during the active phases from $25-90 \%$ (day time) to $5-10 \%$ (night time). Moving activity occupies $20 \%$ of the daily budget. Locomotor activity in the manege is expressed in two ways: movements around the manege and wheel running. The daily rate of running around the manege is about 700 meters. The running differs in diurnal and nocturnal time of day. The running wheels are used only in the nights, when rodents run more than 1000 meters. The specific lemming's activity in the racing wheel is concerned to be a possible indicator of a predisposition to the seasonal migration.
\end{abstract}

KEY WORDS: Ecology, Myopus schisticolor, daily activity.

Alexander D. Mironov [altam@am2030.spb.edu], Biological Institute, Saint Petersburg State University, Oranienbaumskoye shosse 2, Staryi Petergof 198904, Russia; Ol'ga M. Golubeva, Biological Institute, Saint Petersburg State University, Oranienbaumskoye shosse 2, Staryi Petergof 198904, Russia; Tat'yana Yu. Chistova tachistova@mtunet.ru], Severtsov' Institute of Problems of Ecology and Evolution, Russian Academy of Sciences, Leninskii pr. 33, Moscow 117071, Russia; Lyudmila L. Danilkina [ldan@mail.ru], Moscow State University, Biological Faculty, Botanicheskaya ul. 2, Moscow 119899, Russia.

\section{Бюджет суточной активности лесного лемминга Myopus schisticolor (Lilljeborg, 1884) (Rodentia: Cricetidae)}

\author{
А.Д. Миронов, О.М. Голубева, Т.Ю. Чистова, Л.В. Данилкина
}

\begin{abstract}
РЕЗЮМЕ. Изучалась суточная деятельность лесного лемминга в манеже площадью 10 м $^{2}$. Проведено 7 серий многосуточных наблюдений в условиях различного естественного фотопериода. Установлено, что основными составляющими бюджета времени лесного лемминга в экспериментальных условиях являются кормовое поведение и двигательная активность. Кормовая деятельность в суточном бюджете составляет порядка 10\%, а в фазах активности колеблется от 25-90\% (дневные фазы) до 5-10\% (ночные фазы). Временная доля двигательной активности составляет 20\%. Локомоторная активность в манеже выражена двумя видами: перемещения по манежу и бег в колесах. Суточная норма пробежек по манежу составляет порядка 700 м. Пробежки различаются в дневное и темное время суток. Беговые колеса используются только в ночное время, когда зверьки набегают более чем 1000 м. Специфическая активность лесного лемминга в беговом колесе рассматривается как возможный индикатор предрасположенности к сезонной миграции.
\end{abstract}

КЛЮЧЕВЫЕ СЛОВА: экология, Myopus schisticolor, суточная активность.

\section{Introduction}

Wood lemming, Myopus schisticolor (Lilljeborg, 1884 ) is a widespread but rare species (Bol'shakov, 1982; Stenseth \& Ims, 1993; Emel'yanova, 1999). A number of remarkable characteristics make this species highly interesting to study. Lemming's menu consists mainly of the mosses Bryidae (Ivanter, 1975; Tyshkovet al., 1978; Leont'yeva, 1986; Andreassen \& BondrupNielsen, 1991, 1993). It occupies an original ecological niche in taiga-forests living in the thickness of moss cover. Wood lemming is also an interesting object for genetic researches (Gileva et al., 1983; Fredga et al., 1993). Myopus schisticolor is almost inaccessible for studying in the nature because of its concealed way of life and difficulties in catching it. That is why we try to combine information collected from the nature with the data gathered in experiments (Rahmann \& Weber, 1967; Ilmen \& Lahti, 1968; Mironov et al., 1999, 2001). Budget daily activity of wood lemming from a zoological point of view is interesting mainly as a characteristic of inherited mechanisms of adaptation to the immediate environment, as a reflection of possibilities and ways of realization of these mechanisms in using resources of the 
area of inhabitancy. The correlation and succession of various kinds of activity shows the physiological and ecological specific feature. From the variety of animal actions we pay attention to the main ones that are ecologically important: feeding behavior, defense, and moving activity (Daves \& Hatcher, 1998). The lack of the information about wood lemmings' mode of life gives us hope that the results of our observations will supplement the knowledge about the species' ecology.

\section{Materials and methods}

Individuals of wood lemming, Myopus schisticolor (Lilljeborg, 1884) were caught in the autumn of 1996 in the Kandalaksha State Reserve [Zapovednik]. During 1996-1998 we conducted seven series of studies (840 hours in total). We studied behavior of four lemmings: two females (No.2, 22.0 grams; No.6, 31 grams) and two males (No.3, 25 grams; No.7, 22 grams).

We performed a long-term visual control of the behavior of particularly marked individuals. The lemmings were kept in a manege of 3.5 meters in diameter. The height of the manege was $50 \mathrm{~cm}$. There was drawn a net of numerated squares $(50 \times 50 \mathrm{~cm})$. Some remote control studies (through telemonitors) were made in a
Table 1. Structure of daily activity budget in Myopus schisticolor.

\begin{tabular}{|c|c|c|c|c|c|}
\hline \multicolumn{6}{|c|}{ Daily activity $=$ Sum of short periods } \\
\hline \multicolumn{6}{|c|}{ Short activity period $=($ activity time + rest time $)$} \\
\hline \multicolumn{5}{|c|}{ Activity Phase (activity time) $=$ Common activity } & \multirow{4}{*}{$\begin{array}{l}\text { Passive } \\
\text { phase }= \\
\text { rest time } \\
\text { (sleep) }\end{array}$} \\
\hline \multirow{3}{*}{$\begin{array}{l}\text { Brief visits } \\
\text { of shelters } \\
\text { ("hole") }\end{array}$} & \multicolumn{4}{|c|}{$\begin{array}{l}\text { Aboveground activity (activity outside } \\
\text { shelters) }\end{array}$} & \\
\hline & \multirow{2}{*}{$\begin{array}{l}\text { Feeding } \\
\text { activity }\end{array}$} & $\begin{array}{l}\text { Locomot } \\
\text { activity }\end{array}$ & unning) & \multirow{2}{*}{$\begin{array}{l}\text { Other } \\
\text { kinds of } \\
\text { activity }\end{array}$} & \\
\hline & & manege & wheel & & \\
\hline
\end{tabular}

manege of the same height but smaller diameter $(1 \mathrm{~m})$. We made conditions that the lemmings could act free at the experimental site. In the large manege along the wall at the equal distance were placed six wheels for running; in the middle of the manege we put food: apples, oatmeal, dried fruits and milk, water. At the equal distance from the center we put moss of different kinds. Four houses with large entrances were placed between the food troughs. In the small manege ( $1 \mathrm{~m}$ in diameter) we placed a wheel, a house, and the forage. In the laboratory all the wood lemmings were kept separately or in a group under the illumination which is natural for St. Peters-

Table 2. Individual and seasonal usage temporary shelters ("hole") by Myopus schisticolor.

\begin{tabular}{|c|c|c|c|c|c|c|}
\hline \multirow{2}{*}{$\begin{array}{l}\text { Animal } \\
\text { season }\end{array}$} & \multirow{2}{*}{ Period* } & \multirow{2}{*}{$\mathrm{N}^{* *}$} & \multicolumn{2}{|c|}{ Frequency of visit (times) } & \multicolumn{2}{|c|}{ Duration of a visit (min) } \\
\hline & & & $\mathrm{X} \pm \mathrm{Sx}$ & Min-Max & $\mathrm{X} \pm \mathrm{Sx}$ & Min-Max \\
\hline \multirow{3}{*}{$\begin{array}{l}\text { female F2 } \\
\text { autumn }\end{array}$} & $\mathrm{D}$ & 5 & $76.8 \pm 16.86$ & $22-128$ & $154.1 \pm 22.57$ & $88.7-215.3$ \\
\hline & DP & 9 & $1.2 \pm 0.68$ & $0-6$ & $7.5 \pm 3.64$ & $0-30.3$ \\
\hline & LNP & 4 & $65.3 \pm 5.17$ & $54-75$ & $83.8 \pm 14.96$ & $53.4-121.3$ \\
\hline \multirow{3}{*}{$\begin{array}{l}\text { male M7 } \\
\text { autumn }\end{array}$} & $\mathrm{D}$ & 5 & $113.2 \pm 22.46$ & $44-179$ & $326.9 \pm 58.33$ & 143. $7-464.7$ \\
\hline & DP & 7 & $22.4 \pm 5.51$ & $6-50$ & $62.8 \pm 7.53$ & $35.0-92.7$ \\
\hline & LNP & 4 & $8.0 \pm 3.49$ & $2-17$ & $38.6 \pm 20.24$ & $4.0-82.0$ \\
\hline \multirow{3}{*}{$\begin{array}{l}\text { male M3 } \\
\text { autumn }\end{array}$} & $\mathrm{D}$ & 5 & $52.6 \pm 8.33$ & $33-81$ & $305.0 \pm 55.26$ & $174.7-454.2$ \\
\hline & DP & 4 & $5.50 \pm 1.32$ & $3-9$ & $53.9 \pm 26.94$ & $3.03-121.0$ \\
\hline & LNP & 3 & $51.3 \pm 25.21$ & $19-101$ & $138.8 \pm 45.27$ & $84.6-228.7$ \\
\hline \multirow{3}{*}{$\begin{array}{l}\text { male M3 } \\
\text { winter }\end{array}$} & $\mathrm{D}$ & 4 & $25.0 \pm 3.341$ & $18-34$ & $203.0 \pm 21.38$ & $153.2-255.4$ \\
\hline & DP & 8 & $2.1 \pm 0.29$ & $1-3$ & $31.5 \pm 7.60$ & $7.8-68.5$ \\
\hline & LNP & 6 & $8.8 \pm 1.01$ & $5-12$ & $63.7 \pm 8.48$ & $44.7-91.5$ \\
\hline \multirow{3}{*}{$\begin{array}{l}\text { male M3 } \\
\text { summer }\end{array}$} & $\mathrm{D}$ & 5 & $8.2 \pm 2.76$ & $2-18$ & $102.8 \pm 23.57$ & $44.3-144.6$ \\
\hline & DP & 19 & $0.8 \pm 0.27$ & $0-4$ & $8.9 \pm 3.83$ & $0-57.0$ \\
\hline & LNP & 5 & $3.8 \pm 1.20$ & $1-8$ & $60.4 \pm 15.44$ & $33.8-100.3$ \\
\hline \multirow{3}{*}{$\begin{array}{l}\text { female F6 } \\
\text { autumn }\end{array}$} & $\mathrm{D}$ & 9 & $59.1 \pm 10.05$ & $26-116$ & $426.3 \pm 42.23$ & $273.0-642.7$ \\
\hline & DP & 28 & $7.5 \pm 1.41$ & $0-37$ & $57.4 \pm 6.52$ & $0-132.0$ \\
\hline & LNP & 7 & $24.0 \pm 4.32$ & $16-49$ & $154.2 \pm 18.80$ & $109.9-239.8$ \\
\hline \multirow{3}{*}{$\begin{array}{l}\text { female F6 } \\
\text { spring }\end{array}$} & $\mathrm{D}$ & 5 & $32.4 \pm 2.14$ & $27-37$ & $218.3 \pm 35.21$ & $91.7-303.2$ \\
\hline & DP & 14 & $3.3 \pm 0.74$ & $0-9$ & $32.2 \pm 8.66$ & $0-110.0$ \\
\hline & LNP & 5 & $19.6 \pm 3.96$ & $12-33$ & $102.5 \pm 24.76$ & $39.5-186.5$ \\
\hline
\end{tabular}

*D - 24 hours, DP — diurnal phase, LNP — long night phase.

** Number of days or phases. 


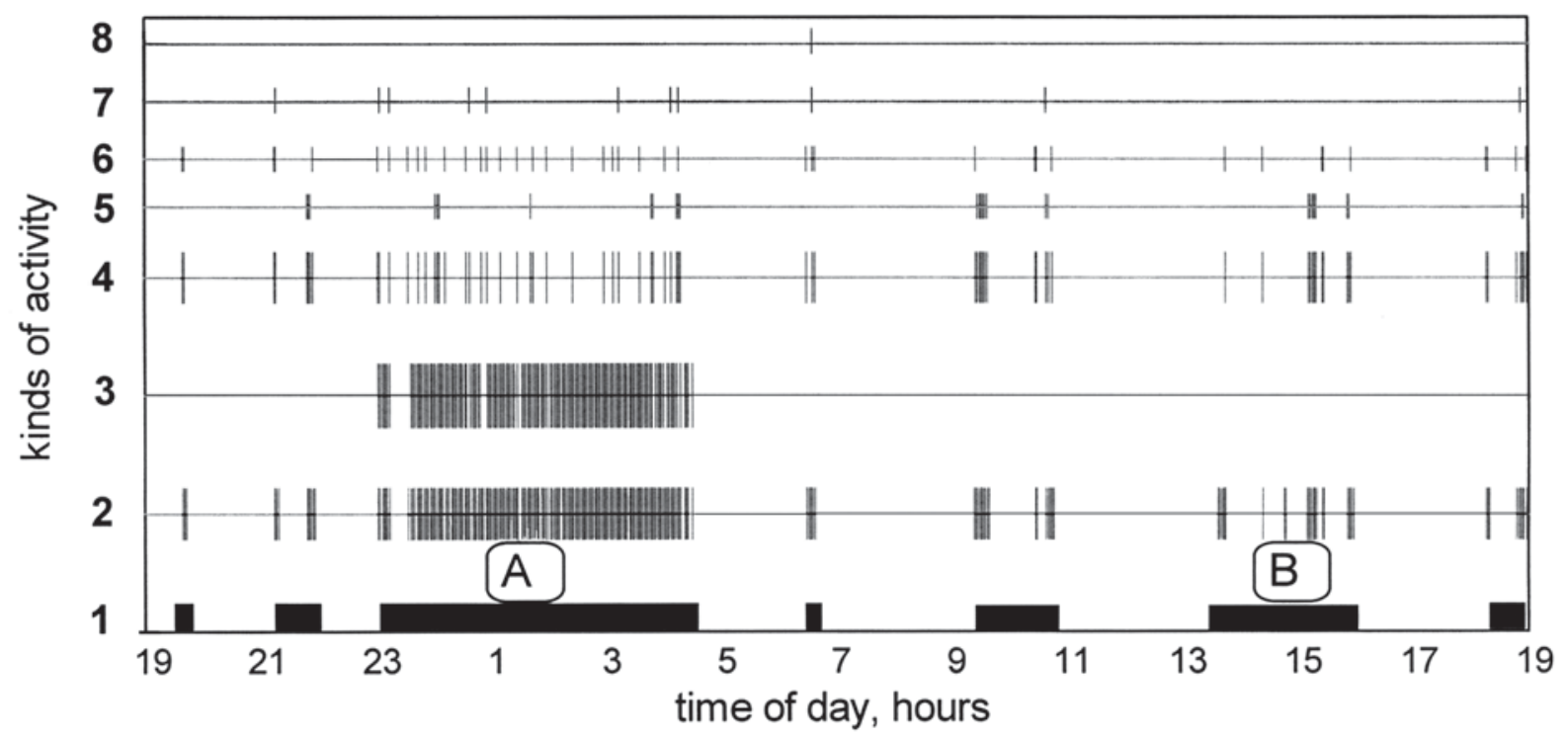

Figure 1. Spectrogram of Myopus schisticolor activity on March 16, 1997 in a big manege.

A - Large Night Phase (23:03-04:31); B — Day Phase (13:38-15:59).

1 - activity phase; 2 - activity above ground; 3 - running in the wheel; 4 - feeding, including moss (5), oat-flakes (6), fruits (7) and water (8).

burg' latitude $\left(\mathrm{N} 60^{\circ}\right)$ corresponding to the season. The temperature was virtually constant $\left(15-18^{\circ} \mathrm{C}\right)$. The photoperiod was natural during the study: long night (lightdarkness ratio is 6:18) in December-January; the equinox (L:D =12:12) in March and September-October; short night (light-darkness ratio is 19:5) in June-July. The period of the studies in the every series continued three-four days. The manege was illuminated through the blue filter with the fluorescent lamp. The individual manners were noticed in daily chain of the development of free flowing rhythm.

We were recording on the audio every lemming's behavior during the whole period of study. We fixed the steps and duration of their actions in detail. In some cases we recorded the whole phases on the video. The quantitative analysis of the time and phase budget and the daily sum of phases was estimated by the main categories of the rodents' behavior: common activity (the activity outside "the hole"), moving activity, feeding, and attendance of the shelters. Locomotor activity was registered in two ways: rotation in the wheels (the duration and number of the rotations) and the movements along the manege (the number of the passed squares). We think that it would be useful to give the detailed figures concerning the every individual that we had studied (Tabs. 1 and 2). The quantitative characteristics of activity will allow us to compare this species with other rodents.

\section{Results}

Budget of time and kinds of activity. During 24 hours the active outcomes from the nestling hole (nestling box in experimental conditions) repeat in a certain period. Graphically the daily behavior of the rodents can be performed in a series of "packets" (Fig. 1). The every block (phase of activity) unites all the actions on the ground, including short attendance "the holes" (boxes).

Daily activity of the wood lemming is an unevenly polyphase rhythm with the prevalence of night activity. There are five-six phases of activity of 90-120 minutes during 24 hours. One of the night phases, the Long Night Phase (LNP) is three-four times longer than others phases (Fig. 1). The value of the summary daily activity is 700-900 minutes. The most intensive part of the activity takes place in the darkness (Rahmann \& Weber, 1967; Mironov et al., 2001).

Budget daily activity. The difference in the behavior of the wood lemmings during day phases and night phases are displayed in the balance of the main components of the activity (Fig. 2). During the day phases the emergency activity predominates because of feeding

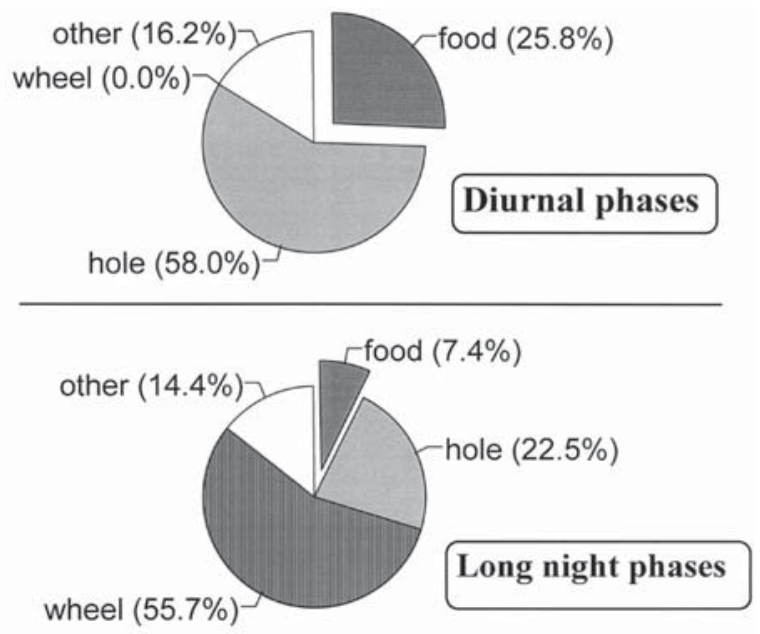

Figure 2. Activity budget in day and night phases in Myopus schisticolor (big manege, female No.3, December 1997). 


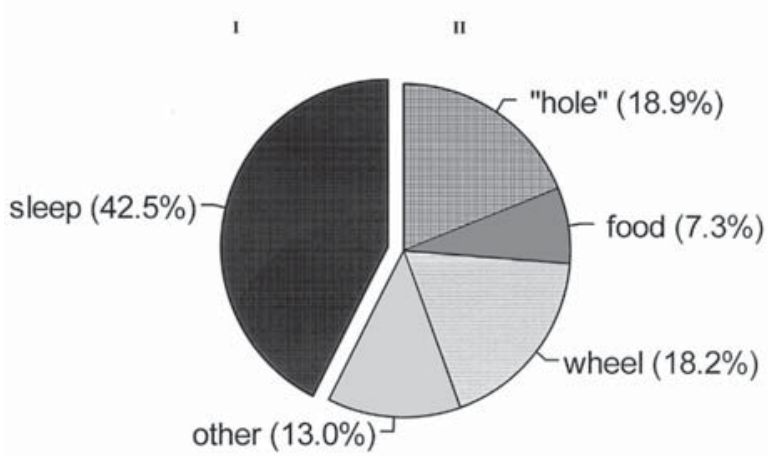

Figure 3. Daily budget in Myopus schisticolor.

necessity, with a few movements and with a considerable part of constant shelters usage. During the night phases (mainly the LNP) moving activity (movements along the manege and hyperactivity in the wheel) increased with feeding activity at a moderate rate. The budget daily activity is a combination of the separate phase's activities (Fig. 3).

Visits of shelters. Analyzing of the "hole" behavior, firstly, we pay attention to the frequency of attendances of the boxes, and their duration. We can point out the preference of one or another shelter like in the nature. We must distinguish the attendance of the temporal shelters (as an activity during the process of usage territorial resources) and stay in the constant nestling hole (box) for a long period for a sleeping. We consider the latter as a brake in the activity. This interval is a division between active phases. The choice of the main box depends on its size and the nestling material. Later lemming close the splits, makes an additional loop-hole, bring more nestling material. The other boxes the rodents actively attend when they move around the manege. Lemmings drop in these boxes when they observe the territory, hide when they feel some danger and store feeding supplies. As a result shelter attendance is one of the main kinds of the activity in active phase. The day and night shelter attendance different. Day phases are characterized by longer stay in the shelters, but fewer number of shelter attendance. The rodents spend $50 \%$ of the phase duration in the shelters $(0-132 \mathrm{~min}, \mathrm{X} \pm \mathrm{Sx}=$ $35.9 \pm 3.69, \mathrm{n}=30)$. At day time the rodent attends about five shelters. But in some short active phases (10-20 min) it does not come into the shelters. The summary of the time spent in the shelters at night is longer then at day: 4-240 min, $\mathrm{X} \pm \mathrm{Sx}=93.6 \pm 9.88, \mathrm{n}=34$. Still the relative part of this activity is $20 \%$ of the night phase. The number of the temporary shelter attendances is about 23 times. The differences between night and day holeactivity are statistically reliable. The rodents use the shelters for safety movement in the afternoon. At night they attend boxes more because of curiosity than of fear. The frequency of night attendance and shortness of stay in the shelters differed a lot from the day behavior. The summary daily exponents of shelter usage compiled about $300 \mathrm{~min}$. in the absolute meanings, which reaches $20 \%$ in the daily budget (Fig. 3 ).
The individual peculiarities in the shelter usage are marked only in the attachment of the concrete specimen to the concrete boxes, which they consider as nestle. It were as rule the boxes in which the rodents were carried over into the large manege or the boxes, where they were put at the first minutes after the beginning of the study, in other words, the place from which the rodents began making themselves familiar with the manege. The season variations in the shelter usage of one specimen exceed sexual and individual characteristics.

Activity outside of the shelters. Attendance of the temporary shelters after leaving the nest-boxes is an important but not the main function of the territory resources usage. All kinds of, so called, visible for the observer activity of lemmings we join in a category called "above-ground activity", i.e. behavior on the ground surface (Mironov et. al., 2001). Firstly, it is feeding behavior, locomotor activity, various forms of comfortable, orientation and social behavior.

Feeding behavior. The behavior bound with search, collection and eating of food, occupies the special place in a number of the ecologically important acts. The base of feeding, as well as in the natural conditions, is various kinds of moss (Pleorozium schreberi, Hylocomium splendens, Polytrichum spp., Dicranum spp.). From an offered assortment of other food, the lemmings preferred the oat-flakes "Hercules". The attitude to other kinds of food (dry milk, fresh apples, water) was spontaneous, the rodents showed individual preferences. For example, the young male No.7 completely skipped dry fruit, when other specimens ate it in the feeder and carried it into the shelter. As we have said above, the rodents might pick out food. As a rule, all food had been eaten at the place of its revelation. The preference of the definite feeders depended on their nearness to the nestbox, wheel for running that the lemming used at that time or some other qualitative features. During experiments with continuous moss substratum the lemmings feeding on its surface. The rodents used the water seldom, onetwo times a day. They lapped it in series of 2-3 seconds.

The rhythm of feeding activity on a daily scale displays irregularly. Short phases are scattered almost regularly on a daily scale both at day and at night time. The day phases can be called "feeding", because the various of the wood lemming behavior is limited to several feeding exits alternating with shelter visits on 10-20 min. The rodents showed carefulness and resistant in locomotion. The lemmings leave the shelters only when they are hungry. On the average the rodents spent for feeding $14.9 \pm 1.42$ $\min (0-70.0, n=34)$. In the budget of short day phases feeding activity occupies about $25 \%$ (Fig. 2).

During the Long Night Phase the lemmings are fed rather short time: $3.15-109.33 \mathrm{~min}, \mathrm{X} \pm \mathrm{Sx}=33.2 \pm 3.94$, $\mathrm{n}=34$. This makes $7 \%$ of the whole night activity (Fig. 2). The differences between the behavior during short and long phases is well displayed in the intensity of eating moss. At day time every incessant feeding lasts about 242 seconds $(1-12500, \mathrm{n}=186)$, at night only $51 \mathrm{sec}(1-$ $600, n=544)$. There is no difference in the consumption other food. 
The individual differences were displayed in the feeding duration or manipulations with food and in the food preference. Total duration of daily feeding behavior is about $100 \mathrm{~min}$, or just $7 \%$ of 24 hours. The part of the feeding activity in the budget of active phases is 10 $30 \%$, but the maximum exponents can reach $60 \%$ and even more.

Locomotor activity. Moving activity is one of the main parts in daily budget. First, we are interested in the locomotor activity. In the laboratory experimental conditions this kind of activity is displayed by two kinds: the immediate movement in the experimental boxes and running in the wheels.

Movements in the manege. The mobility in various phases is different. The large amount of running around the manege is typical for the lemmings during the Long Night Phase. The duration and the extent of some running trajectories at night time reach its maximum. The average length of the running is $\mathrm{X} \pm \mathrm{Sx}=460.6 \pm 63.35 \mathrm{~m}$ (3.5-1317, $n=29$ phases). In the night behavior of the rodents we noted some excitability, appeared in the pace of the shifts and the lack of the exact running aim. The large passed distance in night time is formed at the expense of non-stop with movements of complex trajectory on all square of the manege, with incidental visitations of boxes, feeders and wheel running. In absence of

Table 3. Individual and seasonal feeding activity in Myopus schisticolor.

\begin{tabular}{|l|c|c|c|}
\hline \multirow{4}{*}{ Animal } & \multicolumn{3}{|c|}{ Feeding activity (min) } \\
\cline { 2 - 4 } & $\begin{array}{c}\text { Daily sum (24 } \\
\text { hours) }\end{array}$ & Diurnal Phase & $\begin{array}{c}\text { Long Night } \\
\text { Phase }\end{array}$ \\
\cline { 2 - 4 } & $\begin{array}{c}* \mathrm{X} \pm \text { Sx } \\
\text { Min-Max (n) }\end{array}$ & $\begin{array}{c}\mathrm{X} \pm \mathrm{Sx} \\
\text { Min-Max (n) }\end{array}$ & $\begin{array}{c}\text { X } \pm \text { Sx } \\
\text { Min-Max (n) }\end{array}$ \\
\hline \multicolumn{4}{|c|}{ Autumn (L:D =10:14)** } \\
\hline female & $81.6 \pm 22.06$ & $9.3 \pm 1.62$ & $40.9 \pm 17.98$ \\
F2 & $23.7-118.0(4)$ & $4.9-12.1(4)$ & $12.3-74.1(3)$ \\
\hline male & $45.8 \pm 4.74$ & $6.2 \pm 1.06$ & $23.3 \pm 2.58$ \\
M3 & $37.7-59.5(4)$ & $3.6-8.7(4)$ & $20.5-28.5(3)$ \\
\hline female & $93.2 \pm 9.10$ & $17.5 \pm 2.85$ & $23.0 \pm 6.39$ \\
F6 & $54.2-125.9(8)$ & $3.1-45.9(16)$ & $5.4-50.7(6)$ \\
\hline male & $106.5 \pm 35.64$ & $22.8 \pm 7.04$ & $17.9 \pm 9.02$ \\
M7 & $33.5-171.3(4)$ & $4.2-58.7(7)$ & $3.2-43.4(4)$ \\
\hline \multicolumn{4}{|c|}{ Winter (L:D =6:18) } \\
\hline male & $70.9 \pm 8.58$ & $11.3 \pm 2.12$ & $20.1 \pm 1.68$ \\
M3 & $50.0-87.6(4)$ & $4.9-21.3(8)$ & $15.9-26.4(6)$ \\
\hline \multicolumn{5}{|c|}{ Spring (L:D =12:12) } \\
\hline female & $136.3 \pm 18.84$ & $27.8 \pm 4.94$ & $41.8 \pm 6.84$ \\
F6 & $83.5-175.8(5)$ & $6.7-70.0(15)$ & $25.8-65.0(5)$ \\
\hline \multicolumn{5}{|c|}{ Summer (L:D=19:5) } \\
\hline male & $87.3 \pm 13.35$ & $8.5 \pm 2.34$ & $41.5 \pm 4.26$ \\
M3 & $57.4-131.0(5)$ & $0-36.5(19)$ & $25.2-48.7(5)$ \\
\hline
\end{tabular}

* Mean values (X) and standard error of mean (Sx), under line: minimum-maximum and number of days or phases;

**Light-dark cycle. wheels, the rodent activity is supplemented by jumps on the wall of the manege and running on the perimeter of the manege along the board. As a whole, night movements differed in number of visited objects. The functional significance of the Long Night Phase is locomotor.

The intensity of motor activity during day time is noticeably lower. On the average of 75 phases wood lemming runs at this time $2-225 \mathrm{~min}, \mathrm{X} \pm \mathrm{Sx}=30.7 \pm 5.99$ min. Extended running at this time of day is episodic. The main purpose of movements is visitation the nearest feeder. During day movement the animal is reserved, moves unconfidently. The average value of day movements for 32 days is about $700 \mathrm{~min}$.

The exponents are individually changeable (Tab. 3). For instance, the character of running of female No.6 was more detailed, then the others' running. The movements were quieter with long inspection of the chosen place of the manege, but the number of jumps on the board of the manege was larger. The seasonal changes in the locomotor activity were expressed just in separate maximum values of night running (Tab. 2). For male No.3, as a whole, on the contrary to expectations, daily running activity was less expressed. The seasonal differences for male No.3 were expressed more brightly. It was connected to more clear differences in the photoperiod of the compared light days (October-June) as against the series for female No.6 (October-March). Character of movements in the manege is precipitant, feverish running (in most cases, shifts from one wheel to another). Two other rodents (female No.2 and young male No.7 were watched gathered in group in the large manege in October. The character of movements was quiet with typical concentrations of each rodent in the particular zone of activity in the manege. Male No.7 in the absolute values has big metrics which, in the particular degree, may connect with compensatory substitution of running in the wheels.

Running wheel. The rodents use intensively racing wheels only at night. In some cases when the Long Night Phase extends over the night time the rodents prolonged "wheel activity" at day light. The first rotations in the wheel lemming do carefully, slowly, as though trying the possibilities. The rodent did not seem to wake up yet. The breaks between visiting different wheels are still large. The lemmings bypass the territory of the manege without haste, come to the wheels at different places of the manege, get into them and lazily make some rotations. In this period the rodents use the wheels as study points: sit in the wheels and look down. In short evening phases with approach of activity wheel activity is limited with it. With the beginning of the Long Night Phase the rodents show confidence at movements around the manege and get into the wheels more often. They start running at once it lasts 5-10 $\mathrm{min}$. Sometimes the series are interrupted by short exits from the wheels for 2-5 sec. Then it runs to the nearest box or feeder goes round them and returns into the wheel. The similar behavior is typical for all kinds of rodents that we watched in the manege. The break in long-live, monotonous activity, on the one hand, is some kind of a short rest; on the other 
hand it may be considered as patrolling of the nearest neighborhood. This run in the wheel can last for hours. In the most active night phases the time of wheel activity can reach five hours. In this case the common wheel activity has 2-3 large breaks. The lemming goes out from the wheels but it does not stop the activity in the manege. It is typical that the amount of the rotations in every series is almost the same. The breaks are likely caused by tiredness of the rodents. For example, the limit for male No.3 at intensive run was 6-8 thousand rotations in the wheel. The other lemmings did not make clear breaks, maybe because of the less duration and less intensive wheel activity. Thus the break in the wheel activity descends only in certain conditions. Firstly, at along daily duration of this kind of activity (about 900 min), secondly, it is marked only in the wheel activity, the most energetically wasteful kind of activity and that is why demanding periodic break and, at last, periodic has individual features.

The wheel activity is divided into separate parts with breaks about an hour. The break is not combined with resting phase in the shelters; the wheel activity is interrupted only when the rodent has a rest on a surface. The breaks are displayed on the daily scale. The first break is at $21-22 \mathrm{pm}$, the second is at $2-3 \mathrm{am}$, the third is at 6$7 \mathrm{am}$ and the fourth is at 9-11 am. The amounts of wheel activity in each separate series are comparable among themselves. The number is $6000-8000$ rotations. Although the first series (the evening one is always longer and larger at the amount of rotations), the second and the third (which take place in the Long Night Phase) are surprisingly equivalent in duration and are almost similar at amount of rotations. The fourth series (the morning one) is the shortest and unstable on the range of speed. The first series (evening) starts at once after the sunset and lasts four hours, the second and the third series (night) take place in the Long Night Phase, the second phase begins in 6 hours and the third one in 10 hours after the sunset. And the last (morning) series begins at 3-4 hours before the sunrise.

The average amount of the daily wheel activity is more than $10 \mathrm{~km}$ per a night. In the budget of the night activity the similar activity reaches $50-60 \%$ of the whole duration of the Long Night Phase (Fig. 2). In the budget of common daily activity the part of wheel activity has made about $18 \%$ (Fig. 3).

The relative simplicity of registration the moving activity through the wheels, the methodical comparability of the data has made the wheel parameter the universal value of the experimental ecology. However, the extrapolation of this date on the characteristic of the mobility at natural conditions demands some care. The individual and season differences in the usage of the wheel concern both the fact of running in the wheel and the intensity of its usage. For example, the young male No.7 did not use the wheel. Sometimes it got into the wheel and having sat a little inside, left it without making an attempt to run in the wheel. The intensity of running of the adult lemming No.3, on the contrary, is excessive.
Other activity. Discussing the budget of time of any animal it is particularly impossible to estimate all the diversity of the forms and kinds of activity with identical accuracy. Some processes are swift other are not so isolated, all these makes difficult the methodically uniform registration. Distinguishing the large behavioral blocks connected with the basic forms of the usage of the environment resources, we have to neglect some less significant kinds of activity or units of behavior, that are proper only in this kind. The matter is that at this stage we examine and choose the forms of behavior, which are main and common for any kind of rodents. We want to make a comparative analysis of the species variability in the quantitative exponents, instead of in qualitative what can be specific species characteristics, as for instance manner of grooming or specific of manipulation with unfamiliar subjects. The complexes connected with comfortable behavior, episodically appearing defensive-tentative reaction of the rodents, searching activity and some other we can refer to the same kind of activity. The main reason for joining these activities was methodical reason; the estimation of this kind of activity became a calculating estimate, i.e. all the rest time, which wasn't spent on feeding-, burrow- and movement activities. It is spent about 200 minutes on the "other activity" in the daily balance. Percent of this sort of behavior is identical in the afternoon and night (Fig. 2).

\section{Discussion}

The main problem of the experimental ecology consists in correct extrapolation of the laboratory study and its comparison with the behavior in the nature. It is important not to confuse one thing with another (Davies \& Hatcher, 1998). Poor knowledge of wood lemming ecology demands extra care in the interpretation of the data. The main characteristics of the lemming's behavior in the nature are feeding only with moss, prevalence of the night activity and small space activity (Krivosheev, 1971; Sadykov, 1983; Bobretsov, 1994). Mostly we paid attention to these blocks in our studies. It is habitual more or less even rhythm with periodical feeding frequency for the most part of the rodents that are feeding with green, vegetative parts of plants (Sokolov \& Kuznetzov, 1978; Halle \& Stenseth, 2000). It would be possible to expect more even rhythm of feeding for the wood lemming, because feeding supplies are easily available around nestle. The most amazing factor is the installation of non uniformity of a daily rhythm of activity. It has appeared that wood lemming has different balance of activity in dark and light time of day. Although lemmings eat with clear rhythm that is habitual for all herbivorous, the attendant activity has day and night difference. Day phases of activity are mostly occupied with feeding activity, the movements are minimal. At night time the lemming's behavior is more various, but locomotor activity prevails in the balance (Mironov et al., 1999, 2001).

The amount and distribution of forages in the nature were not able to course excessive territorial shifts. Lem- 
mings are fed both on the surface and under the ground. They eat not far from the nestle and at the same place, as a result the top parts of the moss covers gnawed completely at the area of $1-1.5 \mathrm{~m}^{2}$. In tussocks of green moss lemmings make a net of courses which continues on the surface as kind paths, leading to the places of feeding. The paths are in the thickness of moss in the depth of 10 $20 \mathrm{~cm}$. The length of the courses near nestle is 5-10 m (Krivosheev, 1971; Ochirov, 1974; Ivanter, 1975; Sadykov et al., 1983; Bobretsov, 1994; Kostenko, 2000). The space activity is not large. In the southern Norway it is determined by the results of radio tracking that females use the territory of $285 \mathrm{~m}^{2}$ and males $2144 \mathrm{~m}^{2}$ (Andreassen \& Bondrup-Nielsen, 1991b). In the nature all rodents actively use the whole net of different shelters. They are mainly holes, as for the most of rodents, and also everything that might be used for safe activity and moving at the territory (rubbish of wood, grass, bushes at set). Active usage or an opportunity of using when in need, of a shelter is a natural characteristic of the rodents' territorial behavior. The main shelter is the nestling hole, from which the rodent begins its surface activity and where it returns after the active phase. Moving around the territory rodents come into some shelters now and then. The duration of stays and the frequency of visits depend on a number of reasons. At usual behavior (when there is no danger from aside) the rodents run by (near) their shelters, sometimes they smell the holes, and sometimes they look into it and even penetrate there for a short time (from $5 \mathrm{sec}$ to $5 \mathrm{~min}$ ). We do not know what they do there. They may as well visit temporary feeding supplies, to comfort the nestling shelters, they may check scents of strangers, and, at last they may hide there if they feel danger.

It is necessary to make a net of shelters in the laboratory for adequate reproducing of natural conditions. It is desirable to give the rodents an opportunity of alternative choice. For this we place several boxes. Although, as our experience showed, the lemmings themselves search substitutes of the shelters. When they move, their trajectory lies through protrude objects: feeders, wheels or other units of manage. Having gained some experience the rodents feel themselves almost confidently in the large manage. The possibility of choice allows the rodents to realize the natural course (succession) of acts. In the experimental conditions the stereotype of the feeding behavior and the manner of moving retain (Ilmen \& Lath, 1968; Leont'eva, 1986; Mironov et al., 1999, 2001).

The running around manage are natural expressions of moving activity in the experimental conditions, adequate the territorial shifts of the rodents in the natural conditions with using the resources of the area of their inhabitancy. The direction and length of running allows distinguishing the purpose importance of the object and the succession of the behavioral stimulus that is important for the comparative analysis of the space organization of different settlements of rodents. The qualitative value of movements may be a coefficient of social rank, a coefficient of firmness, territorial confidence. Unfor- tunately, it is difficult to estimate these activities in terms of time on practice because of rapidity of the process. In most cases the running or throws last 1-2 sec. That is why we have some difficulties in the exact estimating of the quantitative structure of the time budget. The locomotor activity of wood lemmings, expressed by running around manage, took place at night. At day mobility of the rodents was minimal and connected only with coming to the nearest trough. Wood lemmings have not got an activity connected with search of food. That is why increased night mobility was not determined by any definite reasons or aims. It was the reaction of excitement. In dark time of a day the locomotor excitability is gradually launched which is often prolonged after sunrise. The termination of this process descends abruptly. There is an impression that it is caused by carrying out some particular task. First of all it throws off simple physical fatigue (Slonim, 1976). By the way, at long night activity it is typical for the rodents to divide the Long Night Part into two parts. It is very tempting to extrapolate the value of manage mobility on the value of movements in the nature. The figures that we have received are quite staked in the value chain, typical for the rodents of such size or dwelling at the similar places (first of all, for bank vole Clethrionomys (Ivanter et al., 1985; Mironov, 1990; Andreassen \& Bondrup-Nielsen, 1991b).

The data of field researches, marking small space mobility, connected it with the sizes of wood lemming, morphological impracticability to fast and long-distance running. The small values of a phase progressions on the surface of manage proved these conclusions. And if we can compare the running around the manage with the movements in the nature, studying the second kind of racing activity (run in a wheel) we have to discuss the possibilities of extrapolation, caution in interpretation of modern views on this category of data (Mather, 1981; Shervin, 1998). Of course it is a specific laboratory expression of moving activity. The high racing activity in the experimental wheels became a specific test on the energetic possibility. Maybe this spontaneous moving concentration is the foundation of the beginning of migration behavior, which is typical for this species. Within the rise of the population the bursts of direct movements are typical for wood lemmings (Novikov, 1941; Teplov, 1952; Semenov-Tyan'-Shan'skii, 1982; Boiko, 1986; Vol'pert \& Shadrina, 1990; Bobretsov, 1994). In such years we can meet lemmings almost in all biotopes, including the populated points. They often swim across rivers. The migration begins in the middle of July. Autumn migration is connected with the increase of the population (Ivanter, 1975; Mordosov, 1980; Krivosheev, 1981; Revin \& Vol'pert, 1982; Sadykov \& Bolshakov, 1983; Savolainen et al., 1984; Henttonen \& Kaikusalo, 1993; Eskelinen, 1997) and as a result the increase of the density, lack of resources all these leads to competitive conflicts (Vol'pert \& Shadrina, 1990). There is an opinion that the seasonal burst of mobility is the result of development of local diseases (Skaren, 1981; Kavaliers et al., 1995). We think that the seasonal migration of wood lemmings is the result of coincidence 
of several reasons. Descends the resonance of the population situation, physiological state of individuals and the features of sporadic concentration of the morning activity, which is typical for this species. A certain critical density of the population should be folded in the population, which increases a stressful level. Autumn migration tells about seasonal energetic possibility (growth of fat). Maybe, the moving features, which are performed in the wheel activity, distinguish wood lemmings from other species which do not migrate. Most likely the same wheel activity will be found at other species, which got used to migrations.

ACKNOWLEDGMENTS. We bring our sincere gratitude to the vice-president of Kandalaksha State Reserve A.V. Koryakin and scientific researcher of this Reserve A. Koryakina for the help in organization of our work in the reservation. We thank for advices, suggestions and valuable remarks Prof. A.I. Naumova. The research was supported by the Russian Fund of Basic Research grant 02-04-48823.

\section{References}

Andreassen H.P. \& Bondrup-Nielsen S. 1991à. Comparison of the effects of a moss diet and a varied diet on the growth of juvenile wood lemmings, Myopus schisticolor // Zeitschrift für Säugetierkunde. Bd.56. Hf.6. P.378-379.

Andreassen H.P. \& Bondrup-Nielsen S. 1991b. Home range size and activity of the wood lemming, Myopus schisticolor // Holarctic Ecology. Vol.14. No.2. P.138-141.

Bobretsov A.V. 1994. [Wood lemming] // Bol'shakov V.N (ed.). [Fauna of the European North-East of Russia. Mammals]. Vol.2. Pt.1. P.220-224 [in Russian].

Bol'shakov V.N. 1982. [Wood lemming in the territory of USSR] // Sokolov V.E. (ed.). [Abstracts of the Third Congress of the Theriological Society]. Moskva: Nauka. P.161-162.

Bondrup-Nielsen S. 1993. Food preference and diet of the wood lemming (Myopus schisticolor) // Stenseth N.Ch. \& Ims R.A. (eds.). The Biology of Lemmings. London, San Diego, New York, etc: Harcourt Brace \& Company Publishers. P.303-309.

Boiko N.S. 1986. [To the ecology of wood lemmings Myopus schisticolor Lillj. in the South of Murmansk Region] // Andreev A.V. (ed.). [The Nature and Economy of the North]. Vol.14. Murmansk: Nauka. P.43-47 [in Russian].

Davies M.S. \& Hatcher A.M. 1998. The energy budget: a useful instrument? // Annales Zoologici Fennici. Vol.35. No.3. P.231-240.

Emel'yanova L.G. 1999. [Space organization of the geographic range of the wood lemming] // Orlov V.N. (ed.). [Abstracts of the Fourth Congress of the Theriological Society]. Moskva: Nauka. P.82 [in Russian].

Eskelinen O. 1997. On the population fluctuations and structure of the wood lemmingMyopus schisticolor//Zeitschrift fur Säugetierkunde. Bd.62. Hf.5. P.293-302.

Fredga K., Fredriksson R., Bondrup-Nielsen S. \& Ims R.A. 1993. Sex ratio, chromosomes and isozymes in natural populations of the wood lemming (Myopus schisticolor) // Stenseth N.Ch. \& Ims R.A. (eds.). The Biology of Lemmings. London, San Diego, New York, etc: Harcourt
Brace \& Company Publishers. P.465-492.

Gileva E.A., Bol'shakov V.N., Sadykov O.F. \& Omariev T.I. 1983. [Chromosome variability and aberrant sex ratio in two Ural populations of lemming, Myopus schisticolor, Lill. 1887] // Doklady Akademii Nauk USSR. T.270. No.2. P.453-456 [in Russian].

Halle S. \& Stenseth N.C. (eds.). 2000. Activity Patterns in Small Mammals. An Ecological Approach // Ecological Studies. Vol.141. Berlin, Heidelberg \& New York: Springer Verlag. 320 p.

Henttonen H. \& Kaikusalo A. 1993. Lemming movements // Stenseth N.Ch. \& Ims R. A. (eds.). The Biology of Lemmings. London, San Diego, New York, etc: Harcourt Brace \& Company Publishers. P.157-186.

Ilmen M. \& Lahti S. 1968. Reproduction, growth and behaviour in the captive wood lemming, Myopus schisticolor // Annales Zoologici Fennici. Vol.5. No.2. P.207-219.

Ivanter E.V. 1975. [Population Ecology of Small-Sized Mammals of Taiga of the North West of USSR]. Leningrad: Nauka. 246 p. [in Russian].

Ivanter E.V., Ivanter T.V. \& Tumanov I.L. 1985. [Adaptive Features of Small-Sized Mammals]. Leningrad: Nauka. 315 p. [in Russian].

Kavaliers M., Colwell D.D. \& Galea L.A.M. 1995. Parasitic infection impairs spatial learning in mice // Animal Behaviour. Vol.50. No.1. P.223-229.

Kostenko V.A. 2000. [The Rodents (Rodentia) of the Far East of Russia]. Vladivostok: Dal'nauka. 210 p. [in Russian].

Krivosheev V.G. 1971. [Wood lemming] // Revin Y.V. (ed.). [Mammals of Yakutia]. Moskva: Nauka. P.297-306 [in Russian].

Krivosheev V.G. 1981. [The factors of quantity regulation of rodents and predatory mammalian in the Kolyma Lowland taiga] // Chernyavskii F.B. (ed.). [Ecology of Mammals of North-East Siberia]. Moskva: Nauka. P.61-82 [in Russian].

Leont'eva I.B. 1986. [To the study of feeding and character of daily activity of wood lemming] // Sokolov V.E. (ed.). [Abstracts of the Fourth Congress of the Theriological Society]. Moskva: Nauka. P.266 [in Russian].

Mather J.G. 1981. Wheel-running activity: new interpretation // Mammal Review. Vol.11. No.1. P.41-51.

Mironov A.D. 1990. Spatial and temporal organization of population in Clethrionomys glareolus // Tamarin R.H., Ostfeld R.S., Pugh S.R., \& Bujalska G. (eds.). Social Systems and Population Cycles in Voles. Basel, Boston \& Berlin: Birkhauser. P.181-192.

Mironov A.D., Golubeva O.M., Chistova T.Y. \& Danilkina L.V. 1999. Experimental ecology of wood Lemming (Myopus schisticolor Lilljeb.) // Ylonen H., Henttonen H., Laajalahti P. \& Niemimaa J. (eds.). Abstracts of the Third European Congress of Mammalogy. Jyvaskyla. P.173

Mironov A.D., Golubeva O.M., Chistova T.Y. \& Danilkina L.V. 2001. [Daily activity of wood lemming (Myopus schisticolor Lilljeb.) // Vestnik Sankt-Peterburgskogo Universiteta, Seriya 3 (Biologiya). Vyp.1 [No. 3]. P.7178 [in Russian].

Mordosov I.I. 1986. [Wood lemming in Western Yakutia] // Sokolov V.E. (ed.). [Abstracts of the Fourth Congress of the Theriological Society]. Moskva: Nauka. P.290-291 [in Russian]. 
Novikov G.A. 1941. [To the ecology of the wood lemming (Myopus schisticolor Lilljeb.) on the Kola Peninsula] // Zoologicheskii Zhurnal. T.20. No.4/5. P.626-631 [in Russian].

Rahmann H. \& Weber F. 1967. Die Steuerung der diurnalen Activitat des Waldlemmings (Myopus schisticolor) durch naturliche und kunstliche Lichtbedingungen (Laboratoriumsversuche) // Zeitschrift für Morphologie und Okologie. Bd.58. Hf.3. S.290-300.

Revin Y.V. \& Vol'pert Y.L. 1982. [About character of reproduction of wood lemming populations in Yakutia] // Revin Y.V. (ed.). [Dynamics of Quantity of Rodents in the Far East of the USSR and Their Role in Natural Assemblages and Agrocoenosses]. Vladivostok: Nauka. P.19 [in Russian].

Sadykov O.F. 1983. [Wood lemming in Southern Urals] // Sokolov V.E. (ed.). [Rare Species of Mammals in the USSR and Their Protection]. Moskva: Nauka. P.76 [in Russian].

Savolainen E., Jaderholm K. \& Kauppinen J. 1984. On the occurrence and migration of the wood lemming (Myopus schisticolor) in Savo in 1963-83 // Kuopion Luonnontieteellisen Museon Sarja. No.6. P.5-22.

Semenov-Tyan'-Shan'skii O.I. 1982. [The Rodents of Murmansk Region]. Murmansk: Knizhnoe Izdatel'stvo. 175 p. [in Russian].

Sherwin C.M. 1998. Voluntary wheel running: a review and novel interpretation // Animal Behaviour. Vol.56. No.1. P.11-27.

Skaren U. 1981. Listeriosis killing wood lemmings, Myopus schisticolor// Zeitschrift für Säugetierkunde. Bd.46. Hf.6. P.395-396.

Slonim A.D. 1976. [The Environment and Behavior. Forming of Adaptive Behavior]. Leningrad: Nauka. 212 p. [in Russian].

Sokolov V.E.\& Kuznetzov G.V. 1978. [Daily Activity Rhythms in Mammals]. Moskva: Nauka. 264 p. [in Russian].

Stenseth N.Ch. \& Ims R.A. 1993. The evolutionary history and distribution of lemmings - an introduction// Stenseth N.Ch. \& Ims R.A. (eds.). The Biology of Lemmings. London, San Diego, New York, etc: Harcourt Brace \& Company Publishers. P.37-43.

Teplova E.N. 1952. [About migration of wood lemming (Myopus schisticolor vinogradovi Sk. et Rajew.) in district of middle current of the Un'ya River] // Zoologicheskii Zhurnal. T.31. No.4. P.642-643 [in Russian].

Tyshkov A.A., Gotfrid A.V. \& Sheftel B.I. 1978. [New data on feeding in wood lemming] // Byulleten' Moskovskogo Obshchestva Ispytatelei Prirody, Seriya Biologicheskaya. T.83. No.4. P.22-26 [in Russian].

Vol'pert J.L. \& Shadrina E.G. 1990. [Ecology of wood lemming (Myopus schisticolor Lilljeb.) in North-East of Yakutia] // Ekologiya. No.4. P.42-50 [in Russian]. 